\title{
Parenting Styles as a Predictor of the Preschool Children's Social Behaviours
}

\author{
Neslihan Durmuşoğlu Saltali \\ Preschool Education Department, Girne American University, Girne, Northern Cyprus of \\ Turkish Republic
}

\section{Hatice Merve İmir \\ Child Protection and Care Services Program, Yıldırım Beyazıt University, Ankara, Turkey}

\begin{tabular}{|c|c|}
\hline Article & \multirow{7}{*}{$\begin{array}{l}\text { The aim of this study is to investigate relationship between children's } \\
\text { social behaviors and parenting styles. Specifically, the study examines } \\
\text { children's aggressive, prosocial and socially inhibited behaviors in } \\
\text { association with parenting dimensions namely warmth, inductive- } \\
\text { reasoning, obedience-demanding and punitive. In addition to this, } \\
\text { children's social behaviors and parenting styles are examined in relation } \\
\text { to children's gender. The research was conducted on } 60-72 \text { month-old } \\
276 \text { children attending preschools in Konya, Turkey. In order to assess } \\
\text { parenting styles, the Child Rearing Questionnaire developed by Sanson et } \\
\text { al. and adapted by Altan was used. This questionnaire has four subscales, } \\
\text { namely inductive reasoning, punishment, obedience demanding behavior } \\
\text { and warmth. The questionnaire was completed by mothers. In order to } \\
\text { assess child social behaviors, the Teacher Assessment of Social Behavior } \\
\text { Scale developed by Cassidy and Asher and adapted by Seven was } \\
\text { applied. This scale was completed by the teachers. According to the study } \\
\text { results, children's social behavior (aggressive, prosocial and } \\
\text { shy/withdrawn) can be predicted significantly by parents inductive } \\
\text { reasoning, warmth and punitive styles toward children. In addition to this, } \\
\text { boys' aggression scores are found to be significantly higher than girls and } \\
\text { girls shyness scores are found to be significantly higher than boys. }\end{array}$} \\
\hline & \\
\hline & \\
\hline & \\
\hline 21.05 & \\
\hline y words: & \\
\hline & \\
\hline
\end{tabular}

\section{Introduction}

Early childhood is regarded as a critical period in human life because experiences during first years of life have long-lasting effect on people. For this reason, offered opportunities and suffered vulnerabilities during early childhood is very important. Opportunities and vulnerabilities with respect to social development in birth to six years of age cannot be examined in isolation; because knowledge about socialization factors is required (Westerberg, 2011). Child-care quality (Peisner-Feinberg et al., 2001; VotrubaDrzal, Coley, \& Chase-Lansdale, 2004); friendship and peer relations (Engle, McElwain, \& Lasky, 2011; Glick \& Rose, 2011) and quality of parenting (Rubin \& Burgess, 2002; Watamura, Phillips, Morrissey, McKartney, \& Bub, 2011) are regarded as possible 
contributors to children's social development. Among these factors, parenting is especially important in children's social development because the way parents care children can influence children's "social functioning" critically and permanently. That's why, previous researches imply relationship between parenting styles and children's social skills (Bornstein \& Bornstein, 2007; Purple, 2005).

Because parents assume special importance in their children's life, different aspects of parenting has been investigated in prior studies (Chamberlain \& Patterson, 1995; Robinson, Mandleco, Olsen, \& Hart, 1995; Mize \& Pettit, 1997). Parenting styles which is an important aspect of parenting refers to intrinsic "emotional" climate in which parent and child relation is embedded. It is also related to the meaning attributed to parents' typical behaviors toward child (Arsivalla, 2009). Parenting styles and short term parenting practices are different because parenting style is the attitude expressed toward the child across a wide-range of situations (Williams et al., 2009).

Certain parenting dimensions are repeatedly examined in several studies in past decade. These dimensions are important because according to Skinner, Johnson and Synder (2005) they "characterize parenting styles" and they form a descriptive scheme for the essential traits and themes of parenting styles. After examining 45 scales used to measure parenting styles, Skinner, Johnson and Synder (2005) reach to the conclusion that there are six dimensions of parenting namely warmth, rejection, structure, chaos, autonomy-support, and coercion.

Parenting styles defined by Baumrind (1966) form the most common model for researches. This model classifies parenting styles based on "parental control" and describes three different styles: authoritarian, authoritative, and permissive (Diaz, 2005). In several studies, these three parenting styles have been found to be predictive of children's developmental outcomes (Aunola, Stattin, \& Nurmi, 2000; Meteyer \& Jenkins, 2009; Rinaldi \& Howe, 2012). Because key socialization agent in children's life is parents (Grusec \& Davidov, 2007); dynamics behind authoritarian, authoritative, and permissive parenting are central to children's socialization process. For this reason, when examining the relationship between parenting styles and children outcomes, researchers usually focus on outcomes in social domains of development (Matestic, 2009; Scaramella \& Leve, 2004; Scaramella, SohrPreston, Mirabile, Robinson, Callahan, 2008). Similarly, Rubin and Burgess (2002) point out that there is a strong association between parenting style and social behaviors.

Theories including attachment theory (Bowlby, 1973), transactional theory (Sameroff, 1983), ecological theory (Bronfenbrenner, 1979), and social learning theory (Bandura, 1977) provide basis to the studies investigating relationship between parenting and children's social behavior (Elgendy, 2010). Contemporary development theories have acknowledged that children are enclosed by several "social contexts", and drawn attention to the significance of uncovering how these contexts are connected with each other and how they affect children's outcomes. These theories' common discourse is that parents have direct or indirect influence on individuals' behaviors. Firstly, in Bowlby's theory of attachment (1988), it is emphasized that children have an inborn tendency to seek proximity from caregivers under uncomfortable conditions. The way parents act in response to these behaviors such as by showing "warmth, rejection or overprotection" influence children's development (Weingold, 2010). Secondly, Bronfenbrenner's ecological theory (1979) relies on the embeddedness of children in various contexts so the theory draws attention to the effects of environment on developing individual. In this theory, children are claimed to be influenced by several contextual factors including parents and primary caregivers (Bronfenbrenner, 1994; Christensen, 2010; Swick \& Williams, 
2006). Thirdly, according to transactional theory (Sameroff, 1983) the developmental outcomes of children are resulted from consecutive reciprocal interplay between children themselves and the experiences family and social context offer (Elgendy, 2010; Sameroff \& Fiese, 2000). Thus, in transactional theory equal emphasis is given to child and surrounding family context because children's behaviors are shaped by combination of children's current behaviors and the family responses to these behaviors. Finally, social learning theory by Bandura (1977) portraits a "learning system" that individuals learn together and from each other (Wals, Hoeven, \& Blanken, 2009). According to this model, behaviors are learned in social environment through the processes of observation, imitation and modeling. Given these theories, it can be inferred that children's behaviors are shaped in the context they are living in. Because parents are the first and most intimate people playing a major role in children's life (Westerberg, 2011), children's interaction with parents and parents' style of responding to their children lay the foundation for children's developing social skills. Thus, it is important to investigate young children's social skills by considering parents' way of child rearing.

In support of theories, it is claimed that three major kinds of parenting namely warm, negative and lax parenting are influential on children's development (Hoeve et al., 2009; McLeod, Weisz, \& Wood, 2007). When examined in detail, it is noticed that negative parenting including harsh and punitive child disciplining practices has been consistently found to be related with behavior problems and non-prosocial behaviors in children (Cornell \& Frick, 2007; Deater-Deckard et al., 2001; Gershoff, 2002; Krevans \& Gibbs, 1996; Romano, Tremblay, Boulerice, \& Swisher, 2005). In contrast to this, warm parenting consisting of positive, nurturing and supportive practices has been found to be associated with fewer behavior problems, better adjustment, positive peer relations and prosocial behaviors in several studies (Garland, 2007; Sroufe, 2005; Strayer \& Roberts, 2004). While parental overprotection and control has been found to be correlated with social anxiety, timidity, behavioral and social problems (Dong, 2010; Gadeyne, Ghesquière, \& Onghena, 2004; Rork, 2004), lax parenting style characterized by poor monitoring, permissiveness and indifference (Harvey, Stoessel, \& Herbert, 2011; Garland, 2007) has been considered to be related with internalizing and externalizing behavior problems, higher physical and relational aggression and lack of self-control (Casas et al., 2006; Garland, 2007; Querido, Warner \& Eyberg, 2002; Thompson, Hollis \& Richards, 2003; Sclafani, 2004).

Researchers have long known that aggression can be identified as early as preschool ages. According to Anderson and Huesmann (2003), aggression is not only a problem for adults, it happens even in toddlers, too but it can be expressed in different ways during early years. Early childhood aggression is a problematic situation because it predicts later adjustment problems (Davenport \& Bourgeois, 2008; Mahoney, 2010; Terzian, 2007). Aggression in childhood even influences intellectual functioning during adult life (Huesmann, Eron, \& Yarmel, 1987).

Huesmann (2010) who has made researches on violence and aggression for decades states that no violence act appears without cumulative situational and personal factors. For this reason, there has been much work dedicated to revealing the possible reasons or contributors of early childhood aggression (Dadds \& Rhodes, 2008; Reebye, 2005). Children who show aggressive behaviors from very early ages are commonly called as "early start youth" (Patterson \& Yoerger, 1993) and these children generally come from family environments where coercive parenting practices are frequent (Terzian, 2007). The reason behind this situation is that aggression starts during early years of life so the roots of it may be situated in family interaction quality (Underwood, Beron, Gentsch, Galperin, \& Risser, 2008). It implies that 
parenting style can be a factor related to the etiology of children's aggressive behaviors.

In contrast to aggression, according to McGinley (2008) parenting also influences children's prosocial behaviors which are defined as behaviors having the intention to assist or to benefit another person (Eisenberg, Fabes, \& Spinrad, 2006). Knafo and Plomin (2006) report that when the affection and discipline of the parents are positive, children's prosocial behaviors increase and similarly when they are negative, children's prosocial behaviors decrease. When parents apply negative disciplining strategies such as punishing them or not reasoning the rules, children get the parental message that they should obey imposed rules but they do not adopt "moral standards" (Knafo \& Plomin, 2006). For this reason, their likelihood to show prosocial behaviors declines. In addition to disciplining practices, it is claimed that overall parenting attitudes like warmth and responsiveness affect children's social behaviors because children who have warm relation with parents have higher prosocial behaviors (Clark \& Ladd, 2000; Knafo \& Plomin, 2006).

In addition to aggressive and prosocial behaviors, growing body of research draws attention to the parental factors as a possible reason of children's socially inhibited behaviors (Hane, Cheah, Rubin, \& Fox, 2008). While warm, responsive and sensitive parenting may decrease or alter children's social inhibition (Early et al., 2002), parental control is regarded as a possible contributor of children's inhibited behaviors. Parents who show over-protective attitudes cause children to be dependent and timid. Those parents try to handle with situations for their children so they limit children's independence. Children raised in such a way cannot find opportunity to acquire coping and problem-solving skills. This brings out socially withdrawn and inhibited behaviors (Rubin, Coplan, \& Bowker, 2009). Taken together, these findings support the claim that parenting has an important role in children's social inhibition.

Although studies usually state that there is a relationship between parenting and children's behaviors, some studies show less significant or no relationship between these constructs. For example, relationship between negative parenting and adverse child developmental outcomes is not very strong in African samples as it is the case for Caucasian samples (Westerberg, 2011). Because parents' expectations and goals regarding their children are influenced by socio-cultural environment, parenting behaviors will likely to change across different nations and ethnic groups. However, great deal of literature with respect to parenting styles and practices has been conducted with Caucian families. As a result, relationship between parenting and children's behaviors among non-Causian families is not well determined (Diaz, 2005). This situation makes it essential to investigate parenting across different nations. Thus, although a lot of study can be encountered about parenting and children's behaviors in literature (Alizadeh, Abu Talib, Abdullah, \& Mansor, 2011) there are not enough studies undertaken which draw attention to the association between children's social outcomes and parenting style in Turkey. Thus, it is necessary to carry out more studies in order to grasp and interpret relationship between parenting styles and children's social behaviors.

Furthermore, concordant with cultural codes of child rearing, parents' child rearing styles are found to be changing depending on children's gender. Parents' gender-related expectations predicts different practices for boys and girls (Moon \& Hoofman, 2008). In a study with 108 Palestinian children by Punamaki, Qouta ve Sarraj (2010), boys reported significantly higher negative parenting treatment than girls. On the other hand, affectionate parenting like intimacy and warmth did not found to be varying across gender. When parents' intimacy and warmth are the case, Russell (1996) states that parental affection is more usually related with girls' misbehaviors than boys' problematic behaviors. In a similar study examining relation 
between parenting styles and children's problem behaviors, it is found that parents show overreaction towards children's problem behaviors which are inconsistent with gender stereotypes. While girls' internalizing problem behaviors and boys' externalizing problem behaviors are associated with lax parenting, girls' externalizing behaviors and boys' internalizing problem behaviors are reacted too strongly by parents (Kim, Arnold, Fisher \& Zeljo, 2005). Generally, parents are found to be applying authoritarian styles with sons but authoritative style with daughters (Russell, Aloa, Feder, Glover, Miller \& Palmer, 1998). However, culture seems to be an important factor in parents' attitudes for gender-related practices. In a study by Gámez-Guadix and Almendros (2015), Spanish parents are found to show all types of discipline more frequently than American parents, but the gender of children is not associated with both Spanish and American parents' disciplining practices. That's why, in this research child gender is aimed to be assessed as an important variable in parents' parenting styles.

(1) All in all, the aim of this study is to investigate relationship between parenting styles and children's social behaviors. Based on this aim, this research tries to answer following questions:

(2) Do parenting styles (warmth, inductive-reasoning, obedience-demanding and punitive) predict young children's social behaviors (aggressive, prosocial and shy/withdrawn behaviors)?

(3) Does social behavior (aggressive behavior, prosocial behavior, shy/withdrawn behavior) of five-to-six year old children differ depending on gender?

(4) Do parenting styles (warmth, inductive-reasoning, obedience-demanding and punitive) of five-to-six year old children's parents differentiate depending on child gender?

\section{Method}

This study used the relational survey model. According to Karasar (2010), relational surveys focus on and try to explain existing situations via different independent variables. Given this, this research aims to investigate children's social behaviors in terms of parenting styles and child gender. In addition to this, parenting styles are examined in terms of children's gender.

\section{Instruments}

In this research, two instruments, namely Child Rearing Questionnaire and Teacher Assessment of Social Behavior Scale were applied. Child Rearing questionnaire is used in order to assess parents' child rearing styles. The instrument is especially preferred because it allows to access valuable data form parents' themselves regarding their styles of rearing and disciplining children. The second instrument, Teacher Assessment of Social Behavior Scale, is used for assessing children's social behaviors. While preschool children get many opportunities to socialize during school days, teachers have chance to observe their activities. That's why, children's social behaviors were asked to be rated by teachers via Teacher Assessment of Social Behavior Scale with respect to children's aggressive, disruptive, prosocial and withdraw behaviors.

\section{Child Rearing Questionnaire:}

Child Rearing Questionnaire was originally developed by Sanson (1994). The Child Rearing Questionnaire (CRQ) consisted of 30 items. The Questionnaire was completed by the mothers. Respondents report the frequency of each behavior on a 5-point scale (1= "Never" 
and 5="Always"). The Child Rearing Questionnaire involved four subscales measuring Inductive Reasoning (e.g., "I try to explain to my child why certain things are necessary."), Punishment (e.g., "I use physical punishment, e.g., smacking, for very bad behavior."), Obedience-Demanding Behavior (e.g., "I expect my child to do what he/she is told to do, without stopping to argue about it."), and Warmth (e.g., "My child and I have warm, intimate times together."). The Turkish version of the CRQ was created by Boratav (2003). Internal consistency for the Turkish version of the CRQ was acceptable, with a Chronbach's alpha of .84 for Punishment, .78 for Obedience- Demanding Behavior, .76 for Inductive Reasoning, and .68 for Warmth (Boratav, 2003). Reliability and validity analysis has been re-examined in the master thesis by Altan (2006). This final form of questionnaire by Altan (2006) has been used in our study.

In Altan's study, scale structure of the CRQ was examined by Varimax rotated factor analysis. This analysis revealed four distinct factors which included items similar to those identified in the Boratav (2003) study. The first factor, Inductive Reasoning included 5 items and the internal consistency value (Cronbach's alpha) for this scale was .79. The second factor, Punishment involved 5 items and had a Cronbach's alpha of 71. The third factor Obedience Demanding Behavior was composed of 3 items with a Cronbach's alpha of .79. Warmth, which was the fourth factor of CRQ, involved 4 items and had a Cronbach's alpha of .64. Six items which cross-loaded in the factor matrix were not included in the scales (Altan, 2006).

\section{Teacher Assessment of Social Behavior Scale}

In order to assess children's social behaviors, Teacher Assessment of Social Behavior Scale developed by Cassidy and Asher (1992) was completed by the teachers. Teachers are asked to rate children on four behavioral dimensions: prosocial, aggressive, shy/withdrawn, and disruptive. Each dimension includes three items so there are totally 12 items in the questionnaire. The responses for each item ranges from "1" ("very uncharacteristic") to "5" ("very characteristic"). Cronbach Alpha was .91 for aggressive, .89 for disruptive, .88 for prosocial, .62 for shy/withdrawn in Cassidy and Asher's (1992) study.

In our study, the Scale adapted to Turkish by Seven (2010) has been completed by teachers. According to Seven's (2010) adaptation scale consists of 12 items and three factors. Factor loadings of the scale items ranged between .66-96. Explained variance of three factors was computed as 79,97 \%. It is observed that factor 1 explains $46,74 \%$ of total variance, factor 2 explains $21 \%$ of total variance and factor 3 explains $12,08 \%$ of total variance. Confirmatory Factor Analysis was calculated in order to confirm three-factor structure. Confirmatory Factor Analysis results are as follows: $\chi 2=99,26(\mathrm{~N}=141, \mathrm{sd}=51, \mathrm{p}=, 00),(\chi 2 / \mathrm{sd})=1,95, \mathrm{GFI}=, 89$, $\mathrm{AGFI}=, 84, \mathrm{SRMR}=.07$ and RMSEA $=.08$. Confirmatory Factor Analysis results confirmed that scale data have well accordance with the ideal data. These findings indicate that threefactor structure of Teacher Assessment of Social Behaviors Scale is valid. Cronbach Alpha reliability coefficient was found .89 for the scale. Cronbach Alfa internal coefficients for factor 1 , factor 2 and factor 3 scores are respectively .95, .94 and .74. All in all, this scale is accepted to be reliable and valid.

\section{Study Group}

15 preschools randomly selected among preschools affiliated to Konya Ministry of National Education are included in our study. According to the data obtained from Governor of Konya, there are 39117 children attending to 314 preschools in Konya (Konya Valiliği, 
2018). Sample size is calculated via Raosoft sampling software (Raosoft, 2017). With a confidence level of $95 \%$ and margin error level of $5 \%$, it is decided to recruit at least 245 preschool children in this research. Until sample size gets satisfying, 15 preschools are randomly added to sample via cluster sampling method. 276 children whose parents allowed to participate in research is recruited from the selected preschools. Finally, sample consists of 276 preschool children attending to 15 different preschools. Data regarding children's social behaviors is collected from teachers; data about parenting styles is obtained from children's mothers (276 mothers).

\section{Process}

Before gathering data, preschools selected for the study has been visited to in order to get teachers' and parents' consent for our research. Meetings were organized with parents in the schools who agreed to participate this research. At the meetings, parents were informed about the study and asked for their consent. Child Rearing Questionnaire is filled by the mothers $(n=276)$ who agreed to participate in the study. Later on, preschool teachers $(n=15)$ filled out the Teacher Assessment of Social Behavior Scale based on their observations.

\section{Data analysis}

The SPSS version 22.0 was used to analyze the data of study. Firstly, Pearson Product Moment Correlation Technique and Basic Linear Regression Technique were used in order to examine effect of parenting styles (warmth, inductive-reasoning, obedience-demanding and punitive) on children social behavior (prosocial behavior, aggressive, shy/withdrawn). Q-Q plot charts were examined for regression analysis in order to determine whether or not a normal distribution occurred, and it was observed that the data did not display a serious deviation from the norm. In addition, T-test was used to compare the group means for children gender as independent variable; parenting styles and child social behavior as dependent variable. The level of significance was set to $\mathrm{p}=.05$.

\section{Results}

As it is seen in Table 1, punitive parenting style is significantly positively correlated with children's aggressive behaviors $(p<0.01)$ and shyness $(p<0.001)$. However, there is a significant negative correlation between punitive parenting style and children's prosocial behaviors. In addition to this, parents' inductive reasoning and warmth are significantly negatively correlated $(p<0.001)$ with children's aggressive and shy behavior while they are significantly positively correlated with children's prosocial behaviors $(\mathrm{p}<0.001)$. Finally, no significant relation was found between obedience-demanding parenting style and children's social behaviors $(\mathrm{p}>0.05)$.

Table 1. Descriptive Statistics: Means, Standard Deviations and Correlation Matrix

\begin{tabular}{lcccccccc}
\hline Variables & Mean & $\mathrm{Sd}$ & 1 & 2 & 3 & 4 & 5 & 6 \\
\hline $\begin{array}{l}\text { 1.Aggressive } \\
\text { behavior }\end{array}$ & 10.67 & 2.33 & - & & & & & \\
$\begin{array}{l}\text { 2.Prosocial } \\
\text { behavior }\end{array}$ & 12.52 & 2.76 &,$- 680^{* *}$ & - & & & & \\
3.Shy/ withdrawn & 5.57 & 2.36 & 0,112 & $-0,342^{* *}$ & - & & & \\
$\begin{array}{l}\text { 4.Inductive } \\
\text { reasoning }\end{array}$ & 20.77 & 3.83 &,$- 185^{* *}$ &, $417^{* *}$ & $-0,207^{* *}$ & - & & \\
$\begin{array}{l}\text { 5.Punishment } \\
\text { 6.Obedience- }\end{array}$ & 7.97 & 3.63 &, $129^{*}$ &,$- 307^{* *}$ &, $213^{* *}$ &,$- 610^{* *}$ & - & \\
Demanding & 8.47 & 3.58 & 0,090 & $-0,050$ & 0,066 & $-0,166$ &, $280^{* *}$ & -
\end{tabular}


$\begin{array}{ccccccccc}\text { 7.Warmth } & 22.07 & 3.92 & -, 186 * * & , 488 * * & -, 184 * * & , 689 * * & -, 553 * * & 0,011 \\ \text { Note: } \mathrm{n}=276 ; & * \mathrm{p}<0.05 ; & * * \mathrm{p}<0.01 & & & & & & \end{array}$

Table 2 illustrates that the basic linear regression models are significant $(\mathrm{p}<0.01)$. The level of children's aggressive behavior can be significantly predicted by parents' inductive reasoning $(\mathrm{p}<0.01)$, warmth $(\mathrm{p}<0.01)$ and punitive parenting styles $(\mathrm{p}<0.01)$. The level of children's prosocial behavior can be significantly predicted by parents' inductive reasoning $(p<0.001)$, warmth $(p<0.001)$ and punitive parenting styles $(p<0.001)$. The level of children's shy/withdrawn behaviors can be significantly predicted by parents inductive reasoning $(\mathrm{p}<0.001)$, warmth $(\mathrm{p}<0.001)$ and punitive parenting styles $(\mathrm{p}<0.001)$.

Table 2. Basic Linear Regression Analysis between Parenting Styles and Children's Social

\begin{tabular}{lccccc}
\multicolumn{2}{c}{ Behavior } & & & \\
\hline Variables & $\mathrm{B}$ & $\mathrm{t}$ & $\mathrm{R}$ & $\mathrm{R}^{2}$ & $\mathrm{~F}_{(1,274)}$ \\
\hline Aggressive behavior & & & & & \\
$\quad$ Inductive Reasoning & $-0,185$ & $-3.117^{*}$ & .18 & .03 & $9.716^{*}$ \\
$\quad$ Punishment & 0,129 & $2.147^{*}$ & .13 & .01 & $4.608^{*}$ \\
$\quad$ Warmth & $-0,186$ & $-3.167^{*}$ & .19 & .03 & 9.408 \\
Prosocial Behavior & & & & & \\
$\quad$ Inductive Reasoning & 0,417 & $7.602^{* *}$ & .42 & .17 & $57.793^{* *}$ \\
$\quad$ Punishment & $-0,307$ & $-5.332^{* *}$ & .31 & .09 & $28.430^{* *}$ \\
$\quad$ Warmth & 0,488 & $9.248^{* *}$ & .49 & .24 & $85.532^{* *}$ \\
Shy/withdrawn & & & & & \\
Inductive Reasoning & $-0,207$ & $-3.501^{* *}$ & .21 & .04 & $12.254^{* *}$ \\
Punishment & 0,213 & $3.610^{* *}$ & .21 & .04 & $13.035^{* *}$ \\
Warmth & $-0,184$ & $-3.101^{*}$ & .18 & .03 & $9.616^{*}$ \\
\hline
\end{tabular}

Note: $\mathrm{n}=276 ; \quad * * \mathrm{P}<0.001 ; \quad * \mathrm{p}<0.01$

Table 3 presents analysis results regarding children's social behaviors and parenting styles across child gender. As it can be seen in Table 3, boys' scores on aggressive behavior are significantly higher than girls' scores $(\mathrm{p}<0.01)$ and girls' shyness scores are significantly higher than boys' scores $(\mathrm{p}<0.05)$. In addition to this, boys' and girls' prosocial behaviors are not significantly different $(p>0.05)$. Finally, parenting styles does not significantly differ based on child gender. In other words, parenting styles toward boys and girls is not significantly different $(\mathrm{p}>0.05)$.

Table 3. Parenting Styles and Children's Social Behavior across Child Gender

\begin{tabular}{|c|c|c|c|c|c|}
\hline Variable & Gender & Mean & Sd. & t-value & p-value \\
\hline \multirow{2}{*}{ Aggressive behavior } & Girl & 9.82 & 4.43 & -2.666 & $0.008 * *$ \\
\hline & Boy & 11.52 & 6.01 & & \\
\hline \multirow{2}{*}{ Prosocial behavior } & Girl & 12.58 & 2.77 & 0.325 & 0.745 \\
\hline & Boy & 12.47 & 2.75 & & \\
\hline \multirow{2}{*}{ Shy/withdrawn } & Girl & 5.89 & 2.50 & 2.305 & $0.022 *$ \\
\hline & Boy & 5.24 & 2.17 & & \\
\hline \multirow{2}{*}{ Inductive Reasoning } & Girl & 21.08 & 3.86 & 1.358 & 0.176 \\
\hline & Boy & 20.46 & 3.79 & & \\
\hline \multirow{2}{*}{ Punishment } & Girl & 7.81 & 3.69 & -0.743 & 0.458 \\
\hline & Boy & 8.13 & 3.58 & & \\
\hline \multirow{2}{*}{ Obedience-Demanding } & Girl & 8.26 & 3.75 & -0.991 & 0.322 \\
\hline & Boy & 8.69 & 3.39 & & \\
\hline \multirow{2}{*}{ Warmth } & Girl & 21.93 & 4.22 & -0.600 & 0.549 \\
\hline & Boy & 22.21 & 3.60 & & \\
\hline
\end{tabular}




\section{Discussion}

In this study, parenting styles are examined in relation with children's aggression, shyness and prosocial behaviors. Several researches imply that positive parenting attitudes like warmth, positive engagement and affection result in positive child outcomes like better adjustment and socialization (Caspi et al., 2004; Smith, Landry, \& Swank, 2000). For example, in a longitudinal study by Eisenberg et al. (2005) it is found that parents' warmth and positive expressivity have a positive effect on children's effortful control which in turn predicts adolescents' externalizing behavior problems. Similarly in our study, results show that punitive parenting styles are positively correlated with children's aggressive behaviors and these behaviors can be predicted by warmth and punitive parenting styles. Our findings overlap with the research conducted by Gadeyne, Ghesquière and Onghena (2004) in which parents and their children were examined for two years in terms of relation between parents' child-rearing and children's adjustment in several domains. The research suggests that mothers' high restrictive control is correlated with externalizing behavior problems. In a similar study by Stormshak, Bierman, McMahon and Lengua (2000) it was reported that parents' punitive interaction is correlated with higher levels child disruptive behaviors particularly aggressive behaviors in home and school settings. These findings are not surprising for us because as Anderson and Huesmann (2003) suggests practices provides the environment for observational learning. While children observe their parents' punitive behaviors, they might develop several knowledge structures encouraging aggression. Children's aggression is not only correlated punitive parenting styles and parents' warmth. Our research also revealed that child aggression can be predicted by parents' inductive disciplinary attitudes and there is a negative correlation between parents' inductive reasoning attitude and children's aggression. Chen, Wang, Chen, \& Liu (2002) researched child-rearing attitudes as predictors of aggression. Their findings are parallel with our findings in terms of association between parents' inductive reasoning and children's aggression. They claim that parental warmth and induction are negatively correlated with child aggression. Findings from previous researches and our research suggest that supportive, inductive and warm parenting attitudes can be beneficial to help children control their aggression.

Children's withdrawn/shyness are found to be negatively correlated with inductive reasoning and warmth parenting styles whereas it is positively related with punitive parenting style. In early works of Mills and Rubin (1990, 1992), parents whose children are withdrawn stated that they would help their children's peer relations by directly instructing them however parents whose children are not socially withdrawn stated that they would encourage their children by discussing and offering alternatives. The implication of this finding overlaps with our finding that children's withdrawn/shyness can be predicted by warmth, punitive and inductive parenting styles. Rubin, Root and Bowker (2010) report that parent-child interaction, parenting beliefs and practices affect the development of social withdrawn in children. Especially, child-rearing attitudes regarded as interfering, destructive, and insensitive may increase the socially withdrawn behaviors. Rubin, Coplan and Bowker (2009) explain the relation between children's withdrawn and parenting styles as follows "Parents who are overly protective and directive tend to over manage situations for their children, restrict their children's behaviors, discourage independence, and control their children's activities" (p. 9). Consistent with our findings, Sandhu and Sarma (2015) find that verbal aggression by parents is associated with higher-level social inhibition and socio-emotional problems. Kwon (2012) similarly suggests that mothers' punitive reactions are positively related with children's socially withdrawn behaviors. Moreover, non-inductive parenting contributes to the heightened levels of social anxiety and social withdrawn (Sandu \& Sarma, 
Children's prosocial behaviors are predicted by several parenting styles including punitive, warmth and inductive-reasoning. Prosocial behaviors mainly characterized as helping behaviors, planned for others' profit and benefit like sharing, volunteering, offering help and showing empathy. According to McGinley (2008) practices and child-rearing styles of parents have an impact on children's prosocial behaviors. For example, higher levels of authoritarian disciplinary techniques are related with non-prosocial behaviors like lower levels of empathy and higher levels of guilt (Cornell \& Frick, 2007). Similarly, in a study by Romano et al. (2005) researching correlates of children's physical aggression and prosocial behaviors, punitive child-rearing practices are found to be among a common predictor of prosocial behaviors in children. According to the study, children with lower levels of prosocial behaviors were raised in families where mothers use more punitive practices. Unlike powerassertive, harsh and punitive practices, inductive parenting attitudes have positive influence on children's prosocial behaviors. According to Krevans and Gibbs (1996), children whose parents are inductive have more empathy; and children who have more empathy are determined to be the children who are more prosocial. In addition to this, other types of parenting practices emphasizing warmth have been found to encourage prosocial behaviors in children and adolescents. For example, in Padilla-Walker, Nielson and Day's (2016) research, it has been revealed that parental warmth and support influence adolescents' prosocial behaviors toward family and friends. Similary, Strayer and Roberts (2004) report that there is a positive link between parental warmth and children's empathic and prosocial behaviors.

Study surprisingly indicated that parents' obedience-demanding attitudes do not correlate with any child behaviors including aggressive, withdrawn and prosocial. Obedience-demanding attitudes were expected to be correlated with especially withdrawn and aggressive behaviors. Such attitudes interfere with children's independence and children can be expected to respond by aggressive resistance or social inhibition. The reason behind this result might be related to children's very young age. In an early study by Higbe (1979), 4 year old children are found to be very obedient. Similarly, in a study conducted with elementary school students it was found that children showed high-level obedience (Zern, 1991). In addition to this, cultures differ in their expectations in terms of parent-child relationships. In our culture, parents usually expect youngers to obey rules and norms; children comply with parents' demands. For this reason, it can be claimed that children internalize the situation and they do not react it in exceptional ways.

According to our study, boys are significantly more aggressive and less shy than girls. In a study conducted with Turkish preschool children, boys are again found to be significantly more aggressive than girls (Gülay-Ogelman, 2013). When different types of aggression is examined, it is found that physical aggression is usually more common among males than females (Juliano, Werner, \& Cassidy, 2006; Kuperschmidt, Bryant, \& Willoughby, 2000) however relational aggression studies show confusing results. While some studies show it is a type of aggression more characteristic of girls (Bonica, Arnold, Fisher, Zeljo, \& Yershova, 2003; Hart, Nelson, Robinson, Olsen, \& McNeilly-Choque, 1998; Ostrov \& Keating, 2004) some studies found that relation aggression is observed more often in boys than in girls (Goldstein, Tisak, \& Boxer, 2002; McEvoy, Estrem, Rodriguez, \& Olson, 2003). Several sociocultural factors can explain the aggression difference between boys and girls. In Turkish culture, as well many other cultures, people have more tendency to tolerate boys' aggressive behaviors. According to Eagly and Steffen's early study (1986) male gender role is defined by several forms of aggression. Authors who have investigated the male gender role have 
reported that that males are expected to be rough, dominant, strong and aggressive However, girls are accepted by their so-called cute and quiet status (Gülay-Ogelman, 2013). Similarly shyness is less tolerable for boys than for girls because it disrupts gender rules in terms of the expected male roles like social assertion and domination (Rubin, Coplan, \& Bowker, 2009). For this reason, girls' shyness and social inhibition may be accepted and rewarded, while boys' shyness is discouraged. Social withdrawal and shyness are usually accepted to be more "characteristic for girls than for boys" (Thijs, Koomen, Jong, Leij \& Leeuwen, 2004). In a study by Kochanska (1991) even toddler girls are found to be more socially withdrawn than boys. Moreover according to Balda and Duhan's study (2010) preschool- age girls show more inhibited/shy behaviors than boys.

Although boys and girls are found to be significantly different in terms of aggression and shyness, no significant difference is found with respect to boys' and girls' prosocial behaviors. Common view regarding gender and prosocial behavior is that females usually show more prosocial behaviors than males. Literature on prosocial behaviors largely supports this common view and reports that girls are more prone to help, collaborate, share and show empathy than boys (Carlo \& Randall, 2002; Perren, Stadelmann, Wyl \& Klitzing, 2007; Yoleri \& Seven, 2014). However, Fabes and Eisenberg (1998) discussing the gender and prosocial behaviors in their meta-analytic study claim that experimental evidence showing females' superiority on prosocial behaviors is uncertain and doubtful. As a result of their meta-analyses, they state "girls' reputations for prosocial behavior are greater than the actual sex difference" (p. 13). They argue that the difference found in previous studies may be due to type of prosocial behavior examined, biased measures of prosocial behaviors and the person giving information about prosocial behavior (self or other-reported prosocial behavior). Moreover, their meta-analyses revealed that gender differences on prosocial behaviors are less observed in young children than in older children. Such arguments by Fabes and Eisenberg (1998) may also explain our finding that preschool girls and boys do not differ on prosocial behaviors.

Our study showed that parents' attitudes do not differ for boys and girls. This is a surprising finding because in an early meta-analytic study of Lytton and Romney (1991) it was found that parents rear boys and girls differently and they encourage different child activities stereotyped for boys and girls (as cited in Kim, Arnold, Fisher \& Zeljo, 2005). Literature regarding parents' disciplining of boys and girls show mixed results. For example, in a study by Conrade and Ho (2001) it is found that fathers and mothers use different parenting styles for their sons and daughters. Fathers are reported to show more authoritative parenting toward boys while mothers showed more authoritative parenting toward girls and permissive parenting toward boys. In a similar study, it is found that boys get significantly more harsh verbal and physical discipline than girls do (Mckee et al., 2007). However, some studies revealed no difference in parents' use of punishment toward sons and daughters (Woodward \& Fergusson, 2002; Holden, Thompson, Zambarano, \& Marshall, 1997). In a report by Halpenny, Nixon and Watson (2010), it was found that there are very few or no difference in parental use of non- aggressive and aggressive disciplining strategies for boys and girls. In other words, aggressive and non-aggressive disciplining strategies are equally distributed across child gender.

Our research findings regarding parent practices and children's social behaviors just describes possible pathways that parents directly or indirectly contribute to the development of child aggression, social inhibition and prosocial behaviors. However, they should not be understood as the only routes or origins of childhood aggression and social inhibition. As Huesmann 
(1997) suggests there is "no simple relation" between parenting and children's antisocial behaviors. Although several researches indicate that there is strong connection between punishment and aggression, it is still not clear which one triggers the other, which one contributes to the other. Do children behave aggressively because of punishment or are children more harshly punished because of showing aggression? Moreover, we still need researches on the moderating effects and other contextual factors contributing the relation between parenting and children's social behaviors.

In light of these findings, it can be suggested that educational programs can be developed for parents and effects of these programs on children's social development can be examined. In addition to this, education in preschool settings should not be restricted with only children and parent education should be regarded as an important point of early childhood education. Parent participation activities should encourage parents not only participation in educational activities but also foster and develop their own parenting skills. Via parent participation activities and school-based intervention programs, parents should be encouraged to learn and apply parenting skills that support children's social behaviors and eliminate child aggression. Because, aggression is relatively stable and persistent in people's life meaning that aggressive children have the risk of becoming aggressive adults (Huesmann, Dubow, \& Boxer, 2009), early precautions involving parents and schools can be advised.

This study has a few limitations that need be addressed. First, the sample size was small. Second, the teachers were used as the informant of children's social behavior. Future studies can be planned to investigate the various effects of the interactions other variables have on preschool children's social behavior.

\section{References}

Alizadeh, S., Abu Talib, M. B., Abdullah, R., \& Mansor, M. (2011). Relationship between parenting style and children's behavior problems. Asian Social Science, 7(12), 195200. http://doi.org/10.5539/ass.v7n12p195

Altan, Ö. (2006). The Effects of Maternal Socialization and Temperament on Children's Emotion Regulation. Master Thesis. Koç University Graduate School of Social Sciences, İstanbul.

Arsivalla, D. D. (2009). The interplay of positive parenting and positive social information processing in the prediction of children's social and behavioral adjustment (Unpublished doctoral dissertation). Graduate Faculty of Auburn University, Alabama.

Anderson, C.A., \& Huesmann, L. R. (2003). Human aggression: A social-cognitive view. In M.A. Hogg \& J. Cooper (Eds.), Handbook of Social Psychology (pp. 296-323). London: Sage Publications.

Aunola, K., Stattin, H., \& Nurmi, J.E., (2000). Parenting styles and adolescents' achievement strategies. Journal of Adolescents, 23, 205-222. http://dx.doi.org/10.1006/jado.2000.0308

Balda, S. \& Duhan, K. (2010). Social inhibition in preschool children: Causes and coping strategies. Journal of Psychology, 1 (2), 79-83.

Bandura, A. (1977). Social Learning Theory. Englewood Cliffs, NJ: Prentice-Hall.

Baumrind, D. (1966) Effects of authoritative control on child behavior. Child Development, 37(4), 887-907.

Baumrind, D. (1967). Child care practices anteceding three patterns of preschool behavior. Genetic Psychology Monographs, 75, 43-88. 
Bonica, C., Arnold, D. H., Fisher, P. H., Zeljo, A., \& Yershova, K. (2003). Relational aggression, relational victimization and language development in preschoolers. Social Development, 12(4), 551-562.

Boratav, A. B. (2003). The role of child temperament, sociocognitive abilities, parenting and social context in the development of prosocial behaviour. (Doctoral dissertation), University of Melbourne, Victoria, Australia.

Bornstein, L., \& Bornstein, M. H. (2007). Parenting styles and child social development. Encyclopedia on early childhood development, 1-4. Available at: http://citeseerx.ist.psu.edu/viewdoc/download?doi=10.1.1.528.635\&rep=rep1\&type $=p$ df Accessed [21.5.2016].

Bowlby, J. (1973). Attachment and Loss, vol. 2, Separation, anxiety and anger. New York: Basic Books.

Bowlby, J. (1988). A secure base: Parent-child attachment and healthy human development. New York: Basic Books

Bronfenbrenner, U. (1979). The Ecology of Human Development. Cambridge, MA: Harvard University Press.

Bronfenbrenner, U. (1994). Ecological models of human development. In M. Gauvain \& M. Cole (Eds.), International Encyclopedia of Education, Vol: 3 (2nd ed., pp: 37- 43). Oxford: Elsevier

Carlo, G., \& Randall, B. A. (2002). The development of a measure of prosocial behaviors for late adolescents. Journal of Youth and Adolescence, 31(1), 31-44.

Casas, J. F., Weigel, S. M., Crick, N. R., Ostrov, J. M., Woods, K. E., Yeh, E. A., \& Huddleston-Casas, C. A. (2006). Early parenting and children's relational and physical aggression in the preschool and home contexts. Journal of Applied Developmental Psychology, 27(3), 209-227. doi:10.1016/j.appdev.2006.02.003

Caspi, A., Moffitt, T. E., Morgan, J., Rutter, M., Taylor, A., Arseneault, L. \& Polo-Tomas, M. (2004). Maternal expressed emotion predicts children's antisocial behavior problems: Using monozygotic-twin differences to identify environmental effects on behavioral development. Developmental Psychology, 40, 149-161. http://doi.org/10.1037/0012-1649.40.2.149

Cassidy, J. \& Asher, S. R. (1992). Loneliness and peer relations in young children. Child Development, 63(2), 350-365

Chamberlain, P. \& Patterson, G. R. (1995). Discipline and child compliance in parenting. In M. H. Bornstein, Marc H. (Eds.), Handbook of parenting: Vol. 4. Social conditions and applied parenting (2nd ed., pp. 205-225). Mahwah, NJ: Lawrence Erlbaum Associates, Publishers.

Christensen, J. (2010). Proposed enhancement of Bronfenbrenner's development ecology model. Education Inquiry, 1(2). doi:10.3402/edui.v1i2.21936

Chen, X., Wang, L., Chen, H., \& Liu, M. (2002). Noncompliance and child-rearing attitudes as predictors of aggressive behaviour: A longitudinal study in Chinese children. International Journal of Behavioral Development, 26(3), 225-233. http://dx.doi.org/10.1080/01650250143000012

Clark, K. E., \& Ladd, G. W. (2000). Connectedness and autonomy support in parent- child relationships: Links to children's socioemotional orientation and peer relationships. Developmental Psychology, 36, 485-498.

Conrade, G., \& Ho, R. (2001). Differential parenting styles for fathers and mothers: Differential treatment for sons and daughters. Australian Journal of Psychology, 53(1), 29-35.

Cornell, A. H., \& Frick, P. J. (2007). The moderating effects of parenting styles in the association between behavioral inhibition and parent-reported guilt and empathy in 
preschool children. Journal of Clinical Child and Adolescent Psychology, 36, 305318. DOI: $10.1080 / 15374410701444181$

Dadds, M. R., \& Rhodes, T. (2008). Aggression in young children with concurrent callousunemotional traits: can the neurosciences inform progress and innovation in treatment approaches?. Philosophical Transactions of the Royal Society of London B: Biological Sciences, 363(1503), 2567-2576. DOI: 10.1098/rstb.2008.0029

Davenport, B. R., \& Bourgeois, N. M. (2008). Play, aggression, the preschool child, and the family: A review of literature to guide empirically informed play therapy with aggressive preschool children. International Journal of Play Therapy, 17(1), 2. http://psycnet.apa.org/doi/10.1037/1555-6824.17.1.2

Deater-Deckard, K., Pike, A., Petrill, S. A., Cutting, A. L., Hughes, C., \& O'Connor, T. G. (2001). Nonshared environmental processes in social-emotional development: An observational study of identical twin differences in the preschool period. Developmental Science, 4, F1-F6.

Diaz, Y. (2005). Associations between parenting and child behavior problems among Latino mothers and children (Doctoral dissertation). Available from ProQuest Dissertations and Theses database. (Document ID 1431540).

Dong, Y. (2010). Parenting practices mediate parenting stress and child inhibited, shy behavior (Unpublished doctoral dissertation). The College of Human Resources and Education, West Virginia University

Eagly, A. H., \& Steffen, V. J. (1986). Gender and aggressive behavior: A meta-analytic review of the social psychological literature. Psychological Bulletin, 100(3), 309- 330.

Early, D. M., Rimm-Kauffman, S. E., Cox, M. J., Saluja, G., Pianta, R. C., Bradley, R. H., et al. (2002). Maternal sensitivity and child wariness in the transition to kindergarten. Parenting: Science and Practice, 2, 355-377.

Eisenberg, N., Fabes, R. A., \& Spinrad, T. L. (2006). Prosocial development. In W. Damon \& R. M. Lerner (Series Ed.) \& N. Eisenberg (Vol. Ed.), Handbook of Child Psychology: Vol. 3. Social, Emotional, and Personality Development (6th ed., pp. 646-718). New York: Wiley.

Eisenberg, N., Zhou, Q., Spinrad, T. L., Valiente, C., Fabes, R. A., \& Liew, J. (2005). Relations among positive parenting, children's effortful control, and externalizing problems: A three-wave longitudinal study. Child Development, 76(5), 1055-1071. doi:10.1111/j.1467-8624.2005.00897.x

Elgendy, S. H. (2010). A Transactional Model of Parenting Practices and Children's Aggressive Behavior in Neighborhood Context (Doctoral dissertation). Available from ProQuest Dissertations and Theses database. (Document ID 3452810).

Engle, J. M., McElwain, N. L., \& Lasky, N. (2011). Presence and quality of kindergarten children's friendships: concurrent and longitudinal associations with child adjustment in the early school years. Infant and Child Development, 20(4), 365-386. DOI: $10.1002 /$ icd.706

Fabes, R., \& Eisenberg, N. (1998). Meta-analyses of age and sex differences in children's and adolescents' prosocial behavior. Manuscript partially published in N. Eisenberg and R. A. Fabes, Prosocial Development. In W. Damon (Ed.), Handbook of Child Development. Retrieved on June 25, 2016 from http://www.public.asu.edu/ rafabes/meta.pdf

Gadeyne, E., Ghesquiere, P., \& Onghena, P. (2004). Longitudinal relations between parenting and child adjustment in young children. Journal of Clinical Child and Adolescent Psychology, 33: 347-358. DOI:10.1207/s15374424jccp3302_16

Gámez-Guadix, M. \& Almendros, C. (2015). Parental discipline in Spain and in the United States: differences by country, parent-child gender and education level. Infancia $y$ 
Aprendizaje: Journal for the Study of Education and Development, 38(3), 569-599. DOI: 10.1080/02103702.2015.1054665

Garland, B. H. (2007). Parenting techniques and parent characteristics associated with child externalizing behavior problems (Unpublished doctoral dissertation). Graduate Studies of Texas A\&M University

Gershoff, E. T. (2002). Parental corporal punishment and associated child behaviors and experiences: A meta-analytic and theoretical review. Psychological Bulletin, 128, 539-579.

Glick, G. C., \& Rose, A. J. (2011). Prospective associations between friendship adjustment and social strategies: friendship as a context for building social skills. Developmental Psychology, 47(4): 1117-32. http://psycnet.apa.org/doi/10.1037/a0023277

Goldstein, S. E., Tisak, M. S., \& Boxer, P. (2002). Preschoolers' normative and prescriptive judgments about relational and overt aggression. Early Education and Development, 13, 23-39.

Grusec, J. E. \& Davidov, M. (2007). Socialization in the family: The roles of parents. In J. E. Grusec \& P. D. Hastings (Eds.), Handbook of Socialization. New York: Guilford Press.

Gülay-Ogelman, H. (2013). Aggression levels of 5- to 6-year-old Turkish children in terms of gender, age, and peer relations variables. Journal of Research in Childhood Education, 27(1), 1-16. DOI: 10.1080/02568543.2012.739987

Halpenny, A. M., Nixon, E., \& Watson, D. (2010). Parents' perspectives on parenting styles and disciplining children. Dublin: Office of the Minister for Children and Youth Affairs. Dublin: The Stationery Office. Retrieved on May 22, 2016 from https://www.tcd.ie/childrensresearchcentre/assets/pdf/Publications/Parents'_Perspectiv es_on_parenting_styles.pdf

Hane, A. A., Cheah, C., Rubin, K. H., \& Fox, N. A. (2008). The role of maternal behavior in the relation between shyness and social reticence in early childhood and social withdrawal in middle childhood. Social Development, 17(4), 798-811.

Hart, C. H., Nelson, D. A., Robinson, C. C., Olsen, S. F., \& McNeilly-Choque, M. K. (1998). Overt and relational aggression in Russian nursery-school-age children: Parenting style and marital linkages. Developmental Psychology, 34, 687-697

Harvey, E., Stoessel, B., \& Herbert, S. (2011). Psychopathology and parenting practices of parents of preschool children with behavior problems. Parenting, 11(4), 239- 263. doi:10.1080/15295192.2011.613722

Higbee, K. L. (1979). Factors affecting obedience in preschool children. The Journal of Genetic Psychology, 134(2), 241-253. doi:10.1080/00221325.1979.10534059

Hoeve, M., Dubas, J. S., Eichelsheim, V. I., Van Der Laan, P. H., Smeenk, W., \& Gerris, J. R. M. (2009). The relationship between parenting and delinquency: A meta- analysis. Journal of Abnormal Child Psychology, 37, 749-775. doi:10.1007/S10802-009-93108

Holden, G. W., Thompson, E. E., Zambarano, R. J., \& Marshall, L. A. (1997). Child effects as a source of change in maternal attitudes toward corporal punishment. Journal of Social and Personal Relationships, 14(4), 481-490. doi:10.1177/0265407597144004

Huesmann, L. R. (1997). No simple relation. Psychological Inquiry, 8(3), 200-204. doi:10.1207/s15327965pli0803_7

Huesmann, L. R. (2010). How to grow a terrorist without really trying: The psychological development of terrorists from childhood to adulthood. In D. Antonius, A. D. Brown, T. K. Walters, J. M. Ramirez \& S. J. Sinclair (Eds.), Interdisciplinary Analysis of Terrorism and Aggression (pp. 1-21). Cambridge, UK: Cambridge Scholars Press. 
Huesmann, L. R., Dubow, E. F., \& Boxer, P. (2009). Continuity of aggression from childhood to early adulthood as a predictor of life outcomes: Implications for the adolescentlimited and life-course-persistent models. Aggressive Behavior, 35(2), 136-149. doi:10.1002/ab.20300

Huesmann, L.R., Eron, L.D., \&Yarmel, P.W. (1987). Intellectual functioning and aggression. Journal of Personality and Social Psychology, 52, 232-240.

Juliano, M., Werner, R. S., \& Cassidy, K. W. (2006). Early correlates of preschool aggressive behavior according to type of aggression and measurement. Journal of Applied Developmental Psychology, 27, 395-410. doi:10.1016/j.appdev.2006.06.008

Karasar, N. (2010). Scientific research methods. Ankara: Nobel Publishing.

Kim, H., Arnold, D. H., Fisher, P. H., \& Zeljo, A. (2005). Parenting and preschoolers' symptoms as a function of child gender and SES. Child \& Family Behavior

Therapy, 27(2), 23-41. doi:10.1300/j019v27n02_03

Knafo, A., \& Plomin, R. (2006). Parental discipline and affection and children's prosocial behavior: Genetic and environmental links. Journal of Personality and Social Psychology, 90(1), 147-164.

Kochanska, G. (1991). Patterns of inhibition to the unfamiliar in children of normal and affectively ill mothers. Child Development, 62, 250-263.

Konya Valiliği. (2018). Ĕgitim: Genel Bilgiler [Education: General Information] Retrieved July 10, 2018, from http://www.konya.gov.tr/genel-bilgiler-egitim

Krevans, J., \& Gibbs, J. C. (1996). Parents' use of inductive discipline: Relations to children's empathy and prosocial behavior. Child Development, 67, 3263-3277. DOI: $10.1111 /$ j.1467-8624.1996.tb01913.x

Kuperschmidt, J. B., Bryant, D., \& Willoughby, M. (2000). Prevalence of aggressive behaviors among preschoolers in Head Start and community child care programs. Behavioral Disorders, 26, 42-52.

Kwon, Y. H. (2012). Children's social withdrawal in relation to mothers' reactions to children's negative emotion and mothers' emotional expressivity. Journal of the Korean Home Economics Association, 50(5), 13-24. Doi: http://dx.doi.org/10.6115/khea.2012.50.5.013

Mahoney, A. J. (2010). Aggression in preschool and predictions of peer reactions how do children expect their peers to feel in response to their behaviors? (Unpublished master thesis). Department of Psychology, George Mason University.

Matestic, P. A. (2009) Trajectories of observed maternal and paternal sensitivity in early and middle childhood: Predicting children's social competence from sensitive parenting. (Unpublished doctoral dissertation) University of Pittsburgh.

Mcevoy, M. A., Estrem, T. L., Rodriguez, M. C., \& Olson, M. L. (2003). Assessing relational and physical aggression among preschool children: Intermethod agreement. Topics in Early Childhood Special Education, 23(2), 51-61. doi:10.1177/02711214030230020101

McGinley, M. (2008). Temperament, parenting, and prosocial behaviors: Applying a new interactive theory of prosocial development (Unpublished doctorate dissertation). The Graduate College at the University of Nebraska. Retrieved on October 8, 2013 from http://digitalcommons.unl.edu/psychdiss/6

Mckee, L., Roland, E., Coffelt, N., Olson, A. L., Forehand, R., Massari, C., . . . Zens, M. S. (2007). Harsh discipline and child problem behaviors: The roles of positive parenting and gender. Journal of Family Violence, 22(4), 187-196. doi:10.1007/s10896-0079070-6 
McLeod, B. D., Weisz, J. R., \& Wood, J. J. (2007). Examining the association between parenting and childhood depression: A meta-analysis. Clinical Psychology Review, 27, 986-1003. doi:10.1016/J.Cpr.2007.03.001

Meteyer, K. B. \& Jenkins, M. (2009). Dyadic parenting and children's externalizing symptoms. Family Relations, 58, 289-302. DOI: 10.1111/j.1741-3729.2009.00553.x

Mills, R. S. L. \& Rubin, K. (1990). Parental beliefs about problematic social behaviors in early childhood. Child Development, 61, 38-151. DOI: 10.1111/j.14678624.1990.tb02767.x

Mills, R. S. L. \& Rubin, K. H. (1992). A longitudinal study of maternal beliefs about children's social behaviors. Merrill-palmer Quarterly, 38(4), 494-512. Retrieved from http://www.jstor.org/stable/23087324

Mize, J. \& Pettit, G.S. (1997). Mothers' social coaching, mother-child relationship style, and children's peer competence: Is the medium message? Child Developmnet, 68, 312332.

Moon, M. \& Hoffman, C. D. (2008). Mothers' and Fathers' differential expectancies and behaviors: Parent X child gender effects. The Journal of Genetic Psychology, 169(3), 261-280, DOI: 10.3200/GNTP.169.3.261-280

Ostrov, J. M., \& Keating, C. F. (2004). Gender differences in preschool aggression during free play and structured interactions: An observational study. Social Development, 13(2), 255-277. doi:10.1111/j.1467-9507.2004.000266.x

Padilla-Walker, L. M., Nielson, M. G., \& Day, R. D. (2016). The role of parental warmth and hostility on adolescents' prosocial behavior toward multiple targets. Journal of Family Psychology, 30(3):331-40. http://doi.org/10.1037/fam0000157

Patterson, G. R. \& Yoerger, K. L. (1993). Developmental models for delinquent behavior. In S. Hodgins, Mental disorder and crime (pp. 140-172). Thousand Oaks: Sage.

Peisner-Feinberg, E. S., Burchinal, M. R., Clifford, R. M., Culkin, M. L., Howes, C., Kagan, S. L. \& Yazejian, N. (2001). The relation of preschool child-care quality to children's cognitive and social developmental trajectories through second grade. Child Development, 72, 1534-1553. http://doi.org/10.1111/1467-8624.00364

Perren, S., Stadelmann, S., Wyl, A. V., \& Klitzing, K. V. (2006). Pathways of behavioural and emotional symptoms in kindergarten children: What is the role of pro-social behaviour? European Child \& Adolescent Psychiatry, 16(4), 209-214. doi:10.1007/s00787-006-0588-6

Punamaki, R. L., Qouta, S., \& Sarraj, E. E. (1997). Relationships between Traumatic events, children's gender, and political activity, and perceptions of parenting styles. International Journal of Behavioral Development, 21(1), 91110. DOI: $10.1080 / 016502597385009$

Purple, M. A. (2005). Correlates of social competence at age two: The roles of temperament and maternal style (Unpublished master thesis). Department of Education and Human Development, Faculty of the Graduate School of the University of Maryland

Querido, J. G., Warner, T. D., \& Eyberg, S. M. (2002). Parenting styles and child behavior in African American families of preschool children. Journal of Clinical Child Psychology, 31, 272-277. doi: 10.1207/S15374424JCCP3102_12

Raosoft. (2017). Sample size calculator. Retrieved April 10, 2017, from http://www.raosoft.com/samplesize.html

Reebye, P. (2005). Aggression during early years-infancy and preschool. The Canadian Child and Adolescent Psychiatry Review, 14(1), 16-20. Retrieved from: http://www.ncbi.nlm.nih.gov/pmc/articles/PMC2538723/ 
Rinaldi, C. M. \& Howe, N. (2012). Mothers' and fathers' parenting styles and associations with toddlers' externalizing, internalizing, and adaptive behaviors. Early Childhood Research Quarterly, 27(2), 266-273. http://dx.doi.org/10.1016/j.ecresq.2011.08.001

Robinson, C. C., Mandleco, B., Olsen, F., \& Hart, C. H. (1995). Authoritative, authoritarian, and permissive parenting practices: Development of a new measure. Psychological Reports, 77, 819-830.

Romano, E., Tremblay, R. E., Boulerice, B., \& Swisher, R. (2005). Multilevel correlates of childhood physical aggression and prosocial behavior. Journal of Abnormal Child Psychology, 33, 565-578.

Rork, K. E. (2004). Influence of parenting factors on childhood social anxiety: Direct observation of parental warmth and control (Unpublished master thesis). Eberly College of Arts and Sciences, West Virginia University.

Rubin, K. H. \& Burgess, K. B. (2002). Parents of aggressive and withdrawn children. In M. H. Bornstein (Ed.), Handbook of parenting: Vol. 1. Children and parenting (2nd ed, pp. 383-418). Mahwah, NJ: Erlbaum.

Rubin, K. H., Coplan, R. J., \& Bowker, J. C. (2009). Social withdrawal in childhood. Annual $\begin{array}{llll}\text { Review } & \text { Psychology, } & \text { 141-171. }\end{array}$ http://doi.org/10.1146/annurev.psych.60.110707.163642

Rubin, K. H., Root, A. K., \& Bowker, J. (2010). Parents, peers, and social withdrawal in childhood: A relationship perspective. New Directions for Child and Adolescent Development, 127, 79-94. http://doi.org/10.1002/cd.264

Russell, A. (1996) Positive parenting and boys' and girls' misbehaviour during a home observation. International Journal of Behavioral Development, 19(2), 291-308, DOI: 10.1080/016502596385794

Russell, A., Aloa, V., Feder, T., Glover, A., Miller, H. \& Palmer, G. (1998). Sex-based differences in parenting styles in a sample with preschool children. Australian Journal of Psychology, 50(2), 89-99. DOI: 10.1080/00049539808257539

Sameroff, A. J. (1983). Developmental systems: context and evolution. In Handbook of Child Psychology: History, Theory, and Methods Vol. 1. (4th ed., pp. 237-294). New York: Wiley

Sameroff, A. J. \& Fiese, B. H. (2000). Transactional regulation: The developmental ecology of early intervention. In J. P. Shonkoff \& S. J. Meisels (Eds.), Handbook of Early Childhood Intervention, (2nd ed., pp.135-159). Cambridge: Cambridge University

Sandhu, G.K. \& Sharma, V. (2015). Social withdrawal and social anxiety in relation to stylistic parenting dimensions in the Indian cultural context. Research in Psychology and Behavioral Sciences, 3(3): 51-59. http://pubs.sciepub.com/rpbs/3/3/2

Sanson, A. (1994). Parenting questionnaire for 3-7 year olds. Unpublished Manuscript. Melbourne: University of Melbourne.

Scaramella, L. V. \& Leve, L. D. (2004). Clarifying parent-child reciprocities during early childhood: The early childhood coercion model. Clinical Child and Family Psychology Review, 7, 89-107.

Scaramella, L., Sohr-Preston, S., Mirabile, S., Robison, S., \& Callahan, K. (2008). Parenting and children's distress reactivity during toddlerhood: An examination of direction of effects. Social Development, 17(3), 578-595.

Sclafani, J. D. (2004). The educated parent: Recent trends in raising children. Westport, CT: Praeger Publishers.

Seven, S. (2010). Adaptation of Teacher Assessment of Social Behavior Scale to Turkish culture. Selcuk University The Journal of Institute of Social Sciences, 23, 193-200. Retrieved from http://dergisosyalbil.selcuk.edu.tr/susbed/article/view/257 
Skinner, E., Johnson, S., \& Snyder, T. (2005). Six dimensions of parenting: A motivational model. Parenting, 5(2), 175-235. doi:10.1207/s15327922par0502_3

Smith, K. E., Landry, S. H., \& Swank, P. R. (2000). The influence of early patterns of positive parenting on children's preschool outcomes. Early Education \& Development, 11, 147-169. http://doi.org/10.1207/s15566935eed1102_2

Sroufe, L. A. (2005). Attachment and development: A prospective, longitudinal study from birth to adulthood. Attachment \& Human Development, 7, 349-367.

Stormshak, E. A., Bierman, K. L., McMahon, R. J., \& Lengua, L. J. (2000). Parenting practices and child disruptive behavior problems in early elementary school. Journal of Clinical Child Psychology, 29(1), 17-29. DOI:10.1207/S15374424jccp2901_3

Strayer, J. \& Roberts, W. (2004), Children's anger, emotional expressiveness, and empathy: relations with parents' empathy, emotional expressiveness, and parenting practices. Social Development, 13, 229-254. http://doi.org/10.1111/j.1467-9507.2004.000265.x

Swick, K. J. \& Williams, R. D. (2006). An analysis of Bronfenbrenner's bio-ecological perspective for early childhood educators: Implications for working with families experiencing stress. Journal of Early Childhood Education, 33(5), 371-378. doi:10.1007/s10643-006-0078-y

Terzian, M. A. (2007). Preventing aggressive behavior by promoting social informationprocessing skills: A theory-based evaluation of the making choices program (Doctoral dissertation). Available from ProQuest Dissertations and Theses database. (Document ID 3262618).

Thijs, J. T., Koomen, H. M., Jong, P. F., Leij, A. V., \& Leeuwen, M. G. (2004). Internalizing behaviors among kindergarten children: measuring dimensions of social withdrawal with a checklist. Journal of Clinical Child \& Adolescent Psychology, 33(4), 802-812. doi:10.1207/s15374424jccp3304_15

Thompson, A., Hollis, C., \& Richards, D. (2003). Authoritarian parenting attitudes as a risk for conduct problems: Results from a British national cohort study. European Child \& Adolescent Psychiatry, 12, 84-91. doi:10.1007/s00787-003-0324-4.

Underwood, M. K., Beron, K. J., Gentsch, J. K., Galperin, M. B., \& Risser, S. D. (2008). Family correlates of children's social and physical aggression with peers: Negative interparental conflict strategies and parenting styles. International Journal of Behavioral Development, 32(6), 549-562. DOİ: 10.1177/0165025408097134

Votruba-Drzal, E., Coley, R. L., \& Chase-Lansdale, P. L. (2004). Child care and low-income children's development: Direct and moderated effects. Child Development, 75, 296312. DOI: 10.1111/j.1467-8624.2004.00670.x

Wals, A. E., Hoeven, N. V., \& Blanken, H. (2009). The acoustics of social learning: Designing learning processes that contribute to a more sustainable world. Wageningen: Wageningen Academic.

Watamura, S. E., Phillips, D. A., Morrissey, T. W., Mccartney, K., \& Bub, K. (2011). Double jeopardy: Poorer social-emotional outcomes for children in the NICHD SECCYD experiencing home and child-care environments that confer risk. Child Development, 82(1), 48-65. doi:10.1111/j.1467-8624.2010.01540.x

Weingold, R. (2010). Family dynamics: A systematic investigation of parenting styles, parent and peer attachment, locus of control and social behaviors (Unpublished doctoral dissertation). College of Education and Human Services, Seton-Hall University

Westerberg, D. (2011). Links between maternal parenting characteristics and development of preschool peer play competence. (Master Thesis). Available from ProQuest Dissertations and Theses database. (Document ID 1505089) 
Williams, L. R., Degnan, K. A., Perez-Edgar, K. E., Henderson, H. A., Rubin, K. H., Pine, D. S., . . . Fox, N. A. (2009). Impact of behavioral inhibition and parenting style on internalizing and externalizing problems from early childhood through adolescence. Journal of Abnormal Child Psychology, 37(8), 1063-1075. doi:10.1007/s10802-0099331-3

Woodward, L. J., \& Fergusson, D. M. (2002). Parent, child, and contextual predictors of childhood physical punishment. Infant and Child Development, 11(3), 213-235. doi:10.1002/icd.252

Yoleri, S., \& Seven, S. (2014). Analyzing effect of age and sex differences on prosocial behavior of preschool children. The Journal of Academic Social Science Studies, 29, 261-270. Doi: /10.9761/JASSS2425

Zern, D. S. (1991). The Nature and extent of obedience in elementary school classrooms. The Journal of Genetic, 152(3), 311-325. Doi: 10.1080/00221325.1991.9914689 